\title{
PENDAMPINGAN DAN PEMBINAAN MANAJEMEN USAHA BAGI PENGUSAHA BAHAN BANGUNAN DI BATU RINGGIT SEKARBELA MATARAM
}

\author{
Hailuddin ${ }^{*}$, Ihsan Rois, Diswandi, Mukmin Suryatni, dan Irwan Suriadi \\ Fakultas Ekonomi dan Bisnis Universitas Mataram \\ ${ }^{*}$ Korespondensi: haliuddin@yahoo.com
}

Diterima 27 September 2018 / Disetujui 13 November 2018

\begin{abstract}
ABSTRAK
Pengelolaan dan penataan serta pengembangan ekonomi usaha kecil dimaksudkan untuk penggalian potensi-potensi kemandirian dan pengembangan ekonomi masyarakat melalui pemberdayaan dan pengembangan ekonomi strategis dalam pengelolaan Sumber Daya potensial secara adil dan berkelanjutan. Dengan harapan penguasaan, kontrol dan pengelolaan usaha akan lebih mandiri. Kegaiatan ini dilakukan pada kelompok maupun individu para pelaku usaha Bahan Bangunan di Batu Ringgit Sekarbela Mataram. Pelaksanaan kegiatan penyuluhan ini menggunakan metode ceramah, diskusi dan ramah tamah. Pada prinsipnya pengembangkan ekonomi strategis berbasis potensi lokal berdasarkan akar budaya/local, dan kearifan lokal masyarakat. Sehingga perlu menumbuh-kembangkan modelmodel pengembangan ekonomi berbasis rakyat kecil atas dasar keswadayaan dan kemandirian. Penguatan-penguatan institusi dan kelembagaan ekonomi masyarakat dalam rangka menumbuhkan sistem perekonomian kolektif dan penguatan permodalan secara swadaya dan mandiri menjadi sangat penting untuk dibangun. Kegiatan pengabdian ini bertujuan untuk memberikan pengetahuan tentang usaha yang mereka jalani, baik secara individu maupun berkelompok agar mereka menyadari perlunya mitra kerja serta kerja kelompok. Demikian juga halnya bagi para pelaku usaha bahan bangunan di Batu Ringgit Sekarbela Mataram. Dalam rangka pemecahan permasalahan yang mereka hadapi, pendekatan kemitraan (usaha bersama) adalah salah satu solusinya, disamping diberikan pengetahuan tentang manajemen usaha dan proses produksinya. Dengan demikian mereka diharapkan lebih baik dan mampu mengelola usahanya dengan baik agar lebih berkembang.
\end{abstract}

Kata kunci: pendampingan, manajemen, bahan bangunan, Sekarbela

\section{PENDAHULUAN}

Berkembangnya sektor ekonomi sekunder akan menciptakan peluang bagi dinamika dunia usaha. Perilaku ekonomi atau sikap kewirausahaan merupakan fungsi dari dinamika dunia usaha. Upaya mendorong perkembangan dunia usaha melalui percepatan perubahan struktur ekonomi terus di upayakan agar tercipta media pembelajaran yang luas bagi pelaku ekonomi kecil untuk mematangkan perilaku ekonomi atau sikap kewirausahaannya. Melalui pendekatan semacam ini diharapkan pelaku ekonomi kerakyatan 
dapat berkembang menjadi fondasi ekonomi yang kokoh bagi perekonomian daerah.

$$
\text { Cukup banyak program }
$$

pemerintah yang telah digulirkan untuk menanggulangi kekurangmampuan para pengusaha kecil umumnya. Program seperti Kredit Usaha Mikro, P2KP, PNPM Mandiri, Bantuan Langsung Masyarkat (BLM) dan lainnya diharapkan dapat meningkatkan kemampuan serta kemandirian kelompok masyarakat ini. Dalam realitanya, program-program pemberdayaan ekonomi yang telah digulirkan tersebut belum bisa menyentuh seluruh golongan. Salah satu kelompok masyarakat yang tidak banyak tersentuh tersebut adalah kelompok usaha mikro kecil.

Disisi lain kelompok ini merupakan komponen yang memiliki peranan cukup penting dalam mengembangkan kehidupan masyarakat, sehingga wajar mendapat perhatian yang cukup dari semua pihak, sehingga mereka akan menjadi mandiri terutama di bidang ekonomi. Pengetahuan yang luas dan pembinaan sangat diperlukan untuk mencapai kemandirian tersebut.

Berbagai persoalan menjadikan para pelaku ekonomi kelompok tersebut kurang berkembang anatarnya adalah kurangnya kemampuan dalam berwirausaha, disamping itu pengetahuan dan pengalaman yang terbatas menjadikan mereka kurang punya inisiatif untuk membuka maupun mengembangkan usaha baru. Disamping itu, masalah permodalan dan belum adanya wadah atau kelompok usaha yang dapat mereka jadikan tempat belajar merupakan faktor penyebab kurangnya kemampuan dalam memasuki bisnis yang nyata.
Berdasarkan uraian di atas, diperlukan upaya serta langkah-langkah nyata dalam neningkatkan kemampuan manajemen usaha bagi UKM termasuk kelompok pedagang bahan bangunan. Dengan pelatihan dan pendampingan manajemen yang intensif diharapkan dapat meningkatkan potensi diri yang dapat membantu perekonomian daerah. Program penyuluhan dan pendampingan ini merupakan salah satu alternatif untuk meningkatkan pengetahuan serta pemahaman pelaku usaha, sehingga mereka dapat mandiri dan dapat memanfaatkan waktu produktif yang dimiliki untuk hal-hal yang lebih bermanfaat terutama dalam mengelola usahanya.

Secara umum permasalahan yang masih menjadi kendala yang dihadapi pelaku UKM antaranya adalah a) masih banyak pelaku usaha yang kesulitan untuk mengembangkan usahanya, b) pengelolaan usaha dilakukan dengan pola sederhana dan secara konvensional, c) masih kesulitan untuk mendapatkan sumber pembiayaan dari sumber formal, dan d) kurangnya pengetahuan dalam bidang kewirausahaan dan koperasi.

Para pelaku usaha informal seringkali menghadapi masalah/kendala terutama yang berkaitan dengan aspek keuangan atau pengelolaan modal, pemasaran dan lainnya dalam mengelola usahanya. Umumnya hal ini sering terlambat diantisipasi oleh para pelaku usaha kelompok ini, akibatnya tanpa disadari kadang berkembang menjadi problem yang kompleks. Kondisi demikian merupakan fenomena yang umum terjadi dan para pelaku usaha tidak melihatnya sebagai suatu kendala. Padahal jika dicermati, beberapa permasalahan/ kendala yang ada seringkali merupakan 
sumber dari sebab terjadinya kegagalan usaha atau penyebab sulitnya berkembang perusahaan.

Kelompok sasaran dalam pengabdian dan pembinaan ini adalah para pelaku usaha penjual bahan bangunan yang ada di wilayah Batu Ringgit Sekarbela Mataram. Dalam pelaksanaannya, khalayak sasaran strategis yang dilibatkan dalam kegiatan ini adalah Aparat Desa (Kades/Kadus/Rukyn Tetangga), Kader karang taruna dan tokoh masyarakat lainnya yang terkait serta pelaku usaha penjual bahan bangunan itu sendiri. Dengan demikian hasil dari kegiatan yang dilakukan dapat diperluas kepada masyaralat lainnya yang menghadapi permasalahan yang sama.

\section{METODE KEGIATAN}

\section{Realisasi Pemecahan Masalah}

Kegiatan pengabdian ini telah dilaksanakan pada hari Ahad 28 Oktober 2018 bertempat di Balai Pertemuan Warga Batu Ringgit Selatan. Guna membantu memecahkan permasalahan yang di hadapi oleh para peserta, maka kerangka pemecahan masalah dalam hal ini mengarahkan para peserta untuk melakukan kemitraan usaha (membentuk usaha kelompok) untuk menampung dan memecahkan permasalahan yang dihadapi. Karena itu materi yang disampaikan disamping itu diberikan pengetahuan tentang manajemen usaha, perencanaan dan cara pengelolaan usaha, pembukuan sederhana, juga tentang tehnik membangun usaha bersama, sehingga mereka termotivasi untuk berusaha dengan tekun dan dapat mengelola usahanya dengan baik.

\section{Khalayak Sasaran Antara yang Strategis}

Kelompok sasaran dalam penyuluhan dan pembinaan ini adalah para pelaku usaha Penjual Bahan Bangunan yang ada di Batu Ringgit Sekarbela Mataram. Dalam kegiatan pengabdian ini khalayak sasaran strategis yang dilibatkan adalah Aparat setempat (Kades/Kadus/Ka-RT), Kader karang taruna dan tokoh masyarakat terkait serta para pelaku usaha. Dengan demikian diharapkan hasil dari kegiatan yang dilakukan dapat diperluas kepada masyaralat lainnya yang menghadapi keadaan yang sama.

\section{Metode Yang Digunakan}

Sehubungan materi yang di sampaikan dalam penyuluhan dan pembinaan ini meliputi motivasi dalam menghadapi tantangan usaha, teknik pengelolaan usaha, pemasaran, menejemen usaha dan kiat pengembangan usaha dan pemanfaatan waktu luang. Tehnik penyampaian materi melalui metode ceramah/pengantar (identifikasi dan membedah masalah UKM), dan setelah ceramah berakhir dilanjutkan diskusi dengan memberikan petunjuk atas kesulitan dan permasalahan yang dihadapi untuk mencari pemecahannya. Selanjutnya membahas rencana tindak lanjut kegiatan serta diahiri dengan pendampingan/konsultasi secara berkala baik berinteraksi langsung maupun melalui kontak personal.

\section{HASIL DAN PEMBAHASAN}

Dengan kegiatan pengabdian ini para peserta mendapat pengetahuan yang sangat mendasar dalam hal membangun dan mengembangkan usahanya, terutama dalam hal; 
1. Pengelolaan usaha barang dagangan: bagaimana cara mengelola usahanya sehingga tujuan yang ingin dicapai yaitu meningkatkan kesejahteraan para pedagang khususnya dan masyarakat pada umumnya dapat diraih.

2. Manfaat dan pentingnya kemitraan dalam usaha: banyak manfaat yang bisa diperoleh pedagang dan masyarakat umum dengan adanya jalinan usaha dalam bentuk kerjasama atau bermitra, terutama dalam memajukan usaha.

3. Kemampuan dalam memanaj usaha, terutama masalah pembukuan usaha, prinsip dan tehnik mengatur keuangan dan pengelolaan modal.

Dengan metode dan kedalaman materi yang disampaikan mendapat sambutan hangat dan respon yang cukup baik dari para peserta penyuluhan. Hal ini tercermin dari keseriusan dan motivasi mereka untuk mengikatkan diri dalam melaksanakan kegiatan usaha yang sedang ditekuninya, baik sebagai pemasok maupun sebagai pedagang. Didukung pula oleh kesungguhan Tim Penyuluh dalam melaksanakan kegiatan ini merupakan modal utama (sebagai faktor pendorong) untuk mengatasi berbagai kelemahan mereka dalam mengelola usahanya.

Terbatasnya anggaran yang tersedia untuk melaksanakan kegiatan pengabdian pada masyarakat merupakan salah satu faktor penghambat, sehingga tidak dapat memberi berbagai kemungkinan inovasi dan aktivitas tambahan yang diperlukan. Disamping itu keterbatasan dana menyebabkan terbatasnya para peserta yang dapat mengikuti penyuluhan semacam ini. Untuk itu perlu ada upaya lanjutan kegiatan penyuluhan dengan berbagai varian kegiatan dengan jumlah peserta yang lebih besar.

\section{KESIMPULAN DAN SARAM}

\section{Kesimpulan}

Dengan pengabdian/penyuluhan ini para peserta mengetahui besarnya manfaat dalam kemitraan usaha atau berkelompok dalam menjalankan usaha. Adanya kerja sama antar kelompok/mitra usaha dapat mengatasi permasalahan yang dihadapinya secara bersama.

Melalui kemitraan usaha, masalah pemasaran hasil, pengadaan bahan baku (barang dagangan) dan hambatanhambatan bisnis lainnya dapat diatasi secara bersama sehingga kelancaran usaha lebih terjaga.

Para peserta masih sangat kurang pengetahuan tentang manajemen usaha, membangun jaringan usaha, memelihara kelangsungan pasokan dan lain-lain, sehingga dengan adanya penyuluhan ini membantu menambah pengetahuan mereka, yang akan memacu usaha mereka dapat berkembang dengan lebih baik.

\section{Saran}

Mengingat jumlah peserta cukup banyak dan yang mendapat kesempatan mengikuti penyuluhan terbatas, serta waktu juga sangat singkat, maka diperlukan upaya untuk melanjutkannya dengan jumlah peserta dan waktu penyuluhan yang lebih banyak, sehingga dalam penyampaian materi akan lebih mantap luas.

Dari jumlah peserta yang hadir, sebagian besar mengharapkan terbentuknya jalinan kerjasama/mitra usaha pedagang sebagai sarana usaha yang sangat potensial. Oleh karena itu disarankan bahwa bagi mereka yang 
belum bermitra atau berkelompok segeralah untuk bermitra kerja atau bergabung dengan kelompok guna memperlancar dan memotivasi pelaku usaha.

\section{DAFTAR PUSTAKA}

Anonim, 2004. Pedoman Klasifikasi Koperasi, Kementrian Koperasi dan Usaha Kecil Menengah Republik Indonesia

Anonim, 2002. Standar Akuntansi Keuangan. Penerbit Salemba Empat, Jakarta.

Halim, Abdul, 2001, Manajemen Keuangan Daerah, UPP AMP YKPN, Yogyakarta.

Kuncoro, Mudrajad, 2004, Otonomi \& Pembangunan Daerah Reformasi, Perencanaan, Strategi dan Peluang, Penerbit Erlangga, Jakarta.

Labni, 2005, Analisis Perbandingan Pemeringkatan Kemampuan Keuangan Daerah pada Pemerintah Daerah Se-Pulau Sumbawa, Mataram.

Hailuddin, 2016. Pemberdayaan Ekonomi Kerakyatan Rumah Tangga Petani Di Karang Baru Rempung Kabupaten Lombok Timur. Mataram.

Hailuddin, 2016. Penataan dan Pengembangan Ekonomi Usaha Kecil di Taman Wisata Loang Baloq, Mataram. 